11. Schiestl C, Neuhaus $K$, Zoller S, et al. Efficacy and safety of propranolol as first-line treatment for infantile hemangiomas. Eur J Pediatr. 2011;170(4): 493-501.

12. Saxena AK, Willital GH. Infrared thermography: experience from a decade of pediatric imaging. Eur J Pediatr. 2008;167(7):757-764.

13. Lavery LA, Higgins $K R$, Lanctot $D R$, et al. Preventing diabetic foot ulcer recurrence in high-risk patients: use of temperature monitoring as a self-assessment tool. Diabetes Care. 2007;30 (1):14-20.

14. Armstrong DG, Holtz-Neiderer $K$, Wendel $C$, Mohler MJ, Kimbriel HR, Lavery LA. Skin temperature monitoring reduces the risk for diabetic foot ulceration in high-risk patients. Am J Med. 2007;120(12):1042-1046.

15. Miki Y. Thermographic evaluations of haemangiomas. Australas J Dermatol. 1975;16(3): 114-117.

16. Desmons F, Houdas Y, Deffrenne C, Lakiere C. Thermographic study of hemangiomas of children. Angiology. 1976;27(9):494-501.
17. Haggstrom AN, Beaumont JL, Lai JS, et al. Measuring the severity of infantile hemangiomas: instrument development and reliability. Arch Dermatol. 2012;148(2):197-202.

18. Talaat AA, Elbasiouny MS, Elgendy DS, Elwakil TF. Propranolol treatment of infantile hemangioma: clinical and radiologic evaluations. J Pediatr Surg. 2012;47(4):707-714.

19. Sans V, de la Roque ED, Berge J, et al. Propranolol for severe infantile hemangiomas: follow-up report. Pediatrics. 2009;124(3):e423-e431.

20. Moukaddam H, Pollak J, Haims AH. MRI characteristics and classification of peripheral vascular malformations and tumors. Skeletal Radiol. 2009;38(6):535-547.

21. Wilmanska D, Antosik-Biernacka A, Przewratil P, Szubert W, Stefanczyk L, Majos A. The role of MRI in diagnostic algorithm of cervicofacial vascular anomalies in children. Pol J Radiol. 2013;78(2):7-14.

22. Bingham MM, Saltzman B, Vo NJ, Perkins JA. Propranolol reduces infantile hemangioma volume and vessel density. Otolaryngol Head Neck Surg. 2012;147(2):338-344.

23. Flors L, Leiva-Salinas C, Maged IM, et al. MR imaging of soft-tissue vascular malformations: diagnosis, classification, and therapy follow-up. Radiographics. 2011;31(5):1321-1341.

24. Georgountzou A, Karavitakis $E$ Klimentopoulou A, Xaidara A, Kakourou T. Propranolol treatment for severe infantile hemangiomas: a single-centre 3-year experience. Acta Paediatr. 2012;101(10):e469-e474.

25. Chang LC, Haggstrom AN, Drolet BA, et al; Hemangioma Investigator Group. Growth characteristics of infantile hemangiomas: implications for management. Pediatrics. 2008;122 (2):360-367

26. Garcia-Romero MT, Chakkittakandiyil A, Pope $E$. The role of infrared thermography in evaluation of proliferative infantile hemangiomas: results of a pilot study. Int J Dermatol. 2014;53(3):e216-e217.

\title{
NOTABLE NOTES
}

\section{Carlo Forlanini, the Dermatologist Who Invented the Cure for Pulmonary Tuberculosis}

Filippo Pesapane, MD; Antonella Coggi, MD; Raffaele Gianotti, MD

Carlo Forlanini was born in 1847 in Milan, Italy, and was the son of Federico Forlanini, the primary doctor from Milan's Fatebenefratelli Hospital. Carlo was the elder brother of Enrico Forlanini, an inventor and aeronautical pioneer well known for his works on helicopters, aircraft, hydrofoils, and dirigibles. Forlanini joined the faculty of medicine at the University of Pavia. In 1866, he volunteered to serve under Giuseppe Garibaldi, and in 1870 he graduated with a thesis focused on cutaneous inflammation entitled "Contribuzione alla Teoria della Piogenesi."1 A close friend in his student days was Camillo Golgi, a man who would later achieve eminence as a histologist and receive the Nobel Prize in $1906 .{ }^{2}$

Milan's main hospital, "Ospedale Maggiore Policlinico" (now "Fondazione Ca' Granda"), attracted Forlanini, and he was accepted in 1871. He spent the next 13 years working in the departments of chronic diseases, eye diseases, and, particularly, skin diseases. In January 1876, he was appointed the head of the skin department, a post he would retain for the next 6 years in order to continue his interest in studying tuberculosis. ${ }^{1}$

In the 1882, the same year that Robert Koch discovered of the tubercle bacillus, Forlanini introduced a new treatment of pulmonary tuberculosis: the artificial pneumothorax. He based this treatment on the intuition that to heal from lung tuberculosis it was necessary suppress its function, or rather to collapse it to eliminate the respiratory trauma. The method is based on the technique of "collassoterapia," which Forlanini also invented. The technique consists of introducing inert gas into the pleural cavity corresponding to the injured lung so that it is placed in a state of functional rest to facilitate healing. ${ }^{3}$ For some 40 years before the introduction of antituberculous drugs, artificial pneumothorax offered hope and, in many cases, healing to patients with tuberculosis around the world.
In 1884, he was appointed chair of Clinica Propedeutica at Turin, Italy, and, finally, in 1900 he obtained the chair of clinical medicine at the University of Pavia, an institution that boasted a glorious tradition. This was where Giulio Bizzozero had made discoveries on the physiologic characteristics of blood, where Paolo Mantegazza had signaled the importance of the glands of internal secretion, and where Edoardo Bassini had developed his method of treating inguinal hernia. ${ }^{2}$ By all accounts, ForIanini was a popular teacher. Among his pupils was Scipione RivaRocca, who introduced the first practical sphygmomanometer in $1896 .{ }^{1}$

In 1913, Forlanini became a senator of the Italian Republic, and at the time of his death in 1918 he had been proposed for the Nobel Prize in Medicine. After his death, a research fund for the study of tuberculosis was created in his name. In 1934, the "Carlo Forlanini Institute" was founded in Rome, comprising a complex of sanatorium, university clinic, laboratories museum, and research center. ${ }^{1}$

Author Affiliations: Dermatology Unit, "Fondazione IRCCS Ca' Granda, Ospedale Maggiore Policlinico," Department of Medical-Surgical and Transplantation Physiopathology, University of Milan, Milan, Italy.

Corresponding Author: Filippo Pesapane, MD, Dipartimento di Fisiopatologia Medico-Chirurgica e dei Ttrapianti, Università degli Studi di Milano-Fondazione IRCCS Ca' Granda Ospedale Maggiore Policlinico, Milano, Via Pace, 9, Milano 20100, Italy (filippopesapane@gmail.com).

1. Sakula A. Carlo Forlanini, inventor of artificial pneumothorax for treatment of pulmonary tuberculosis. Thorax. 1983;38(5):326-332.

2. Berti Bock G, Vial F, Heymans G, Rulliere R. Critical considerations on the work of Carlo Forlanini (1847-1918 [in Italian]. Minerva Med. 1980;71(26):1879 1883.

3. Forlanini C. A contribuzione della terapia chirurgica della tisi: ablazione del pulmone: pneumotorace artificiale. Gazzetta degli Ospedale e della Cliniche di Milano. 2013;3:537-585. 